\title{
Article
}

\section{Increasing Foreign Aid for Inclusive Human Development in Africa}

\author{
Asongu, Simplice and Nwachukwu, Jacinta Chikaodi \\ Available at http://clok.uclan.ac.uk/25149/ \\ Asongu, Simplice and Nwachukwu, Jacinta Chikaodi ORCID: 0000-0003-2987- \\ 9242 (2018) Increasing Foreign Aid for Inclusive Human Development in \\ Africa. Social Indicators Research, 138 (2). pp. 443-466. ISSN 0303-8300
}

It is advisable to refer to the publisher's version if you intend to cite from the work. http://dx.doi.org/10.1007/s11205-017-1668-3

For more information about UCLan's research in this area go to http://www.uclan.ac.uk/researchgroups/ and search for < name of research Group>.

For information about Research generally at UCLan please go to http://www.uclan.ac.uk/research/

All outputs in CLoK are protected by Intellectual Property Rights law, including Copyright law. Copyright, IPR and Moral Rights for the works on this site are retained by the individual authors and/or other copyright owners. Terms and conditions for use of this material are defined in the policies page.

\section{CLoK}

Central Lancashire online Knowledge www.clok.uclan.ac.uk

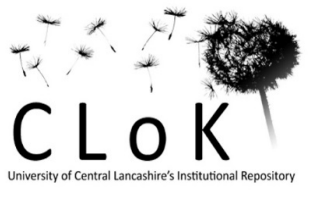



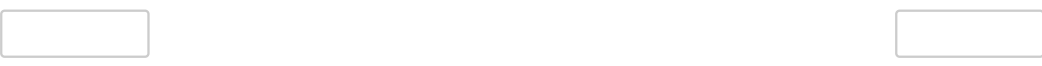


\section{$\underline{\text { A G D I Working Paper }}$}

\section{WP/17/020}

Increasing foreign aid for inclusive human development in Africa

Forthcoming in: Social Indicators Research

\section{Simplice A. Asongu}

African Governance and Development Institute,

P.O. Box 8413 Yaoundé, Cameroon.

E-mail: asongusimplice@yahoo.com

\section{Jacinta C. Nwachukwu}

School of Economics, Finance and Accounting,

Faculty of Business and Law, Coventry University Priory Street, Coventry, CV1 5FB, UK.

Email: jacinta.nwachukwu@ coventry.ac.uk 
Research Department

\title{
Increasing foreign aid for inclusive human development in Africa
}

\section{Simplice A. Asongu \& Jacinta C. Nwachukwu}

January 2017

\begin{abstract}
In the light of evidence that poverty has been decreasing in all regions of the World with the exception of Africa, where about 45 percent of countries in Sub-Saharan Africa did not achieve the Millennium Development Goal (MDG) extreme poverty target. Therefore, this study assesses whether increasing foreign aid improves inclusive human development. The investigation is on 53 African countries for the period 2005-2012. The empirical analysis is based on (i) the Generalised Method of Moments (GMM) to control for persistence in inclusive human development, simultaneity and time-invariant omitted variables and (ii) Instrumental Variable Tobit Regressions to control for simultaneity and the limited range in the dependent variable. The adopted foreign aid variables are: 'humanitarian assistance', 'action on debt' 'aid for social infrastructure', 'aid to the productive sector', 'aid to the multi sector', 'aid for economic infrastructure' and 'programme assistance'.

The following findings are established. From the GMM specifications, there are (i) synergy effects from 'aid to the productive sector' and a positive net effect from 'programme assistance' and (ii) negative net impacts from 'aid to social infrastructure' and human assistance, albeit with positive marginal effects. From Instrumental Variable Tobit regressions (i) there is a synergy effect from 'aid for economic infrastructure' and (ii) there are negative net impacts from 'aid for social infrastructure', 'aid to the productive sector' and human assistance, albeit with positive marginal effects. Policy implications are discussed.
\end{abstract}

JEL Classification: B20; F35; F50; O10; O55

Keywords: Foreign Aid; Sustainable Development; Africa 


\section{Introduction}

The positioning of this inquiry on whether increasing foreign aid would enhance inclusive human development in Africa is motivated by four main factors, namely: (i) increasing noninclusive development in Africa; (ii) the central role of inclusive human development in the post-2015 sustainable development agenda, (iii) calls for foreign aid to be increased in order to help poor countries achieve the Sustainable Development Goals (SDGs) and (iv) gaps in the literature.

First, over the past two decades while the African continent has enjoyed a growth resurgence that began in the mid-1990s (see Fosu, 2015a), the benefits of economic prosperity has not trickled down to the poor for inclusive human development. This worrisome fact has recently been substantiated by a World Bank report on the Millennium Development Goal (MDG) extreme poverty target which has shown that such has been decreasing in all regions of the world with the exception of Sub-Saharan Africa (SSA). In this sub-region, 45 percent of nations were substantially off-track from achieving the MDG extreme poverty target (World Bank, 2015). In response to this inequality and poverty trend in Africa, Kuada (2015) has suggested a paradigm shift to 'soft economics' (or human capability development) as means of understanding the non-inclusive development tendencies in Africa. It is important to note that, though in a more contemporary context, the suggestion of Kuada is almost identical with the suggestion from Amartya Sen (1997, 1999). Moreover, Sen first proposed and elaborated the concept of "human capability" (Sen, 1979a, 1979b) and the notion of "development as capability expansion" in later years.

Second, the relevance of the investigation also builds on challenges to the post-2015 sustainable development agenda which for the most part are centred on the imperative to reverse world exclusive development trends and which consolidate global inclusive development tendencies. The growth-'exclusive development' relationship in Africa falls within the former framework. In theory, the conception, definition and measurement of 'inequality adjusted human development' that is used as the outcome variable (see Section 3) is consistent with at least six of the seventeen SDGs, namely: Goal 1(end poverty in all its forms everywhere), Goal 2 (end hunger, achieve food security and improved nutrition and promote sustainable agriculture),Goal 3 (ensure healthy lives and promote well-being for all ages), Goal 4 (ensure inclusive and equitable quality education and promote lifelong learning opportunities for all),Goal 8 (promote sustained, inclusive and sustainable economic growth, 
full and productive employment and decent work for all) and Goal 10 (reduce inequality within and among countries) ${ }^{1}$.

Third, there are growing calls for more targeted foreign aid in Africa in order to (i) correct non-inclusive issues encountered in the MDGs and (ii) address concerns of inclusive development like poverty reduction and employment enhancement in the post-2015 development agenda (see Jones \& Tarp, 2015; Simpasa et al., 2015; Jones et al., 2015; Asongu \& Nwachukwu, 2016a).

Fourth, this inquiry also addresses a relevant gap in the literature, notably: the lack of a study that has investigated whether increasing development assistance can enhance inclusive human development in Africa. The two main strands in the literature have included (i) policies through which foreign aid can be reinvented and (ii) debates on the relevance of foreign aid in development outcomes.

With respect to the former perspective, both qualitative and quantitative literature has been substantially documented on how development assistance can be reinvented for more effective outcomes in development (Easterly, 2008). This stream of literature includes: the Sachs experiment of eliminating poverty and cost effectiveness schemes by the World Bank (see Banerjee \& He, 2008); amputation, intensification and 'policy change'-related reforms (see Pritchett \& Woolcook, 2008); Randomised Control Trials (Duflo \& Kremer, 2008); imperatives for more rigorous evaluations (Pritchett, 2008); less emphasis on 'planning for solutions' and more emphasis on 'searching for solutions' (Easterly, 2006); 'aid vouchers' for incentives in better/competitive delivery of aid services (Easterly, 2002, 2008); new global initiatives (see Radelet \& Levine, 2008) and Advanced Purchase Commitment (Kremer, 2008).

On the last strand, the debate on the importance of development assistance in African development is still widely open. Whereas there are optimistic views on the outcomes of development assistance when effective policies are designed and adequate transmission channels considered (see Gyimah-Brempong \& Racine, 2014; Kargbo \& Sen, 2014; Asiedu, 2014), there are also perspectives in the literature that are pessimistic on the role of development assistance in African development (Marglin, 2013; Obeng-Odoom, 2013; Titumir \& Kamal, 2013; Monni \& Spaventa, 2013; Wamboye et al., 2013; Ghosh, 2013; Krause, 2013; Banuri, 2013).

\footnotetext{
${ }^{1}$ The interested reader can refer to Michel (2016) for a full list of SDGs.
} 
In the light of the above, the purpose of this inquiry is not to engage in the debate about whether foreign aid is positive or not in development outcomes. The study is more concerned with how increasing various categories/types of foreign aid affect inclusive human development.

The rest of the study is structured as follows. Section 2 involves the theoretical underpinnings and motivation for reinventing development assistance while Section 3 covers the data and methodology. The results are presented and discussed in Section 4 whereas Section 5 concludes with policy implications and remarks on future research directions.

\section{Theoretical Underpinnings and Reinvention of Foreign Aid}

The theoretical connections between foreign aid channels and inclusive development in poor countries are based on two main theoretical underpinnings which have been documented to elicit the: African poverty tragedy and effectiveness of foreign aid in development outcomes (see Asongu \& Nwachukwu, 2016a).

First, consistent with Kuada (2015), the growing levels of poverty in Africa invite a substantial rethink of development paradigms on the continent. The author has proposed a shift towards 'soft economics' (or human capability development) as a means of understanding poverty in Africa. The proposed shift in paradigm from strong economics (or structural adjustment policies) is broadly consistent with the 'foreign aid'-oriented theoretical propositions from Asongu and Jellal (2016) which suggest that inclusive development and economic growth can be enhanced in the continent if foreign aid is channelled via mechanisms that reduce the taxation burden borne by the private sector. Moreover, the paradigm from Kuada (2015) for eliciting the absence of inclusive development and high unemployment in Africa is in line with a recent stream of African development literature on the need to reinvent foreign aid in order to address challenges in the post-2015 sustainable development agenda (see Jones \& Tarp, 2015; Simpasa et al., 2015; Jones et al., 2015; Page \& Söderbom, 2015; Page \& Shimeles, 2015).

Second, it is important to also examine why reinventing foreign aid for non-exclusive development is relevant in contemporary development literature. Accordingly, the growing request in scholarly circles for foreign aid to be reinvented for inclusive and sustainable development has coincided with the Piketty's celebrated book that has joined the stream of literature (e.g., Fields [2001]) debunking Kuznets' conjectures. Asongu (2016) has surveyed about 200 recently published scientific studies and argued that developed countries should use 
foreign aid to orient developing countries within the framework of Piketty; i.e. that inequality increases with industrialisation. This is contrary to the foundations of Kuznets on an inverted U-shape relationship between inequality and industrialisation. The underlying suggestions are deeply motivated by (i) the inability of most African countries to achieve the MDG extreme poverty target and (ii) continental challenges in the post-2015 sustainable development agenda.

\section{Data and Methodology}

\section{1 Data}

This paper investigates a panel of 53 African nations with data from three principal sources, namely, the: (i) Organisation of Economic Co-operation and Development (OECD), (ii) the World Bank Development Indicators and (iii) the United Nations Development Program (UNDP). The sample is for the period 2005-2012. The choice of the sample is motivated by the need to restrict instrument proliferation and limit over-identification in an adopted estimation approach or Generalised Method of Moments (GMM). The justification of periodicity has also been used in recent literature on the relationship between inclusive development and development assistance (see Asongu \& Nwachukwu, 2016a). Within the framework of our study, we notice from a preliminary investigation that (i) a higher number of years in every cross section (or T) biases estimated coefficients because of the proliferation of instruments and (ii) a $\mathrm{T}$ with a maximum value of 8 ensures that instruments are not higher than the number of cross sections, in post-estimation diagnostics (see Section 4). It is interesting to note that, the rule of thumb needed to avoid a rise in the number of instruments is that they should not be higher than the number of periods in cross sections.

The adopted variable to be explained is the inequality-adjusted human development index (IHDI). This dependent indicator is in line with recent inclusive development literature (see Asongu et al., 2015). The Human Development Index (HDI) controls for the national average of achievements in three main areas. They are (i) "decent" standards of living, (ii) knowledge and (iii) long life and health. In addition to controlling for benefits in domains of income, education and health, the IHDI further controls for the distribution of these achievements among the population by accounting for the mean value of each dimension with regards to inequality. Both the HDI and IHDI are in Gross National Income (GNI)per capita adjusted for purchasing power parity (PPP US \$). 
As shown in Table 1, a plethora of aid explanatory variables are adopted by the study in the quest to account for heterogeneity in development assistance. Accordingly, there are growing calls in scholarly circles to account for types and sectors of foreign aid in order to provide a more complete view of the role of foreign aid in development outcomes (see Quartey \& Afful-Mensah, 2014; Asiedu \& Nandwa, 2007). The selected development assistance indicators include: humanitarian assistance, action on debt, programme assistance, aid to the multi sector, aid to the productive sector aid for economic infrastructure and aid for the social infrastructure ${ }^{2}$.

Since, multiple foreign aid variables are involved; they are also used complementarily as control variables. Two more control variables are added in order to enhance the control for variable omission bias ${ }^{3}$. (1) GDP per capita is chosen as a variable of control because it logically has a high degree of substitution with GNI per capita which is a component of the HDI. (2) Globalisation in the perspective of trade openness has been established to influence inclusive development (Mshomba, 2011; Asongu, 2013; Chang, 2008; Stiglitz, 2007).

The summary statistics, definitions and sources of the variables are presented in Table 1. From the summary statistics, it is apparent that the variables can be compared from the perspective of mean values. Furthermore, based on corresponding variations, reasonable linkages are expected to emerge. The foreign aid indicators are defined in terms logarithms in order to ensure that means and corresponding standard deviations are comparable.By taking all the foreign aid indicators in logarithms, we make an implicit assumption that foreign aid has diminishing marginal returns on IHDI. Such a theoretical assumption is consistent with our results which will be discussed in terms of marginal and net effects.

The indicators of foreign assistance denote disbursements of multilateral aid from the Development Assistance Committee (DAC) countries. Table 2 discloses a correlation matrix which provides us with insights into expected signs and helps the study to avoid potential issues of multicollinearity. It is essentially because there is some degree of substitution among the aid indicators that these indicators are used in distinct sets of specifications in order to avoid multicollinearity concerns which affect expected relationships.

\footnotetext{
${ }^{2}$ It is important to note that various aid components affect the dependent variable in various ways. For instance, 'aid to the productive sector' may more likely affect the income component of the dependent variable compared to 'humanitarian aid' which could save lives and increase the 'life expectancy' component of the dependent variable.

${ }^{3}$ It important to note that in order to avoid instrument proliferation and limit over-identification, some recent studies based on GMM have not included control variables (see Osabuohien \& Efobi, 2013, p. 303).
} 
Table 1: Definition of variables, sources and Summary statistics

\begin{tabular}{|c|c|c|c|c|c|c|}
\hline & Definitions/ Sources & Mean & S.D & Min & Max & Obs \\
\hline $\begin{array}{l}\text { Inclusive } \\
\text { development }\end{array}$ & $\begin{array}{l}\text { Inequality Adjusted Human Development Index } \\
\text { UNDP, World Bank WDI. }\end{array}$ & 0.486 & 0.130 & 0.129 & 0.809 & 351 \\
\hline $\begin{array}{l}\text { Aid to Social } \\
\text { Infrastructure }\end{array}$ & $\begin{array}{l}\text { Foreign aid directed at human development } \\
\text { drivers such as education, water supply and } \\
\text { sanitation (log)/OECD. }\end{array}$ & 2.012 & 0.622 & 0.113 & 3.077 & 424 \\
\hline $\begin{array}{l}\text { Aid to } \\
\text { Economic } \\
\text { Infrastructure }\end{array}$ & $\begin{array}{l}\text { Foreign aid directed at infrastructures like } \\
\text { transport, communication and energy (log)/OECD. }\end{array}$ & 0.812 & 1.201 & -2.000 & 3.067 & 415 \\
\hline $\begin{array}{l}\text { Aid to } \\
\text { Productive } \\
\text { sector }\end{array}$ & $\begin{array}{l}\text { Foreign aid directed at the productive sector like } \\
\text { agriculture, industry, mining, construction, trade } \\
\text { and tourism }(\log ) / O E C D \text {. }\end{array}$ & 1.017 & 0.830 & -1.699 & 2.741 & 424 \\
\hline $\begin{array}{l}\text { Aid to Multi } \\
\text { Sector }\end{array}$ & $\begin{array}{l}\text { Foreign aid directed at other sectorial development } \\
\text { like rural development }(\log ) / O E C D \text {. }\end{array}$ & 1.023 & 0.682 & -1.699 & 2.541 & 424 \\
\hline $\begin{array}{l}\text { Programme } \\
\text { Assistance }\end{array}$ & $\begin{array}{l}\text { Foreign aid directed towards programme related } \\
\text { assistance like food aid, disaster and war } \\
(\log ) / O E C D \text {. }\end{array}$ & 1.116 & 0.924 & -2.000 & 3.103 & 350 \\
\hline Action on debt & Aid directed towards debt relief $(\log ) / \mathrm{OECD}$. & 0.535 & 1.310 & -2.000 & 4.045 & 321 \\
\hline $\begin{array}{l}\text { Humanitarian } \\
\text { Assistance }\end{array}$ & $\begin{array}{l}\text { Aid allocated for Humanitarian Assistance } \\
(\log ) / O E C D\end{array}$ & 0.894 & 1.004 & -2.000 & 3.038 & 400 \\
\hline GDP per capita & Gross Domestic Product Per Capita (Log)/WBDI & 2.949 & 0.501 & 2.157 & 4.142 & 416 \\
\hline Trade & $\begin{array}{l}\text { Imports plus Exports as a percentage of GDP } \\
\text { (Log)/WBDI. }\end{array}$ & 4.298 & 0.413 & 3.111 & 5.368 & 396 \\
\hline
\end{tabular}

S.D: Standard Deviation. Min: Minimum. Max: Maximum. Obs: Observations. Log: logarithm. OECD : Organisation for Economic Co-operation \& Development. UNDP: United Nations Development Programme. WDI: World Bank Development Indicators.

Table 2: Correlation matrix

\begin{tabular}{rrrrrrrrrlll}
\hline EcoInfra & ProdSect & MultiSec & Prog. Assis & ActionDebt & HumanAssis & \multicolumn{1}{l}{ GDPpc } & \multicolumn{1}{l}{ Trade } & \multicolumn{1}{l}{ IHDI } & \\
\cline { 2 - 7 } & 0.760 & 0.784 & 0.284 & 0.111 & 0.419 & -0.108 & -0.211 & -0.184 & SocioInfra \\
& 0.675 & 0.693 & 0.203 & 0.155 & 0.150 & 0.086 & -0.107 & 0.029 & EcoInfra \\
& & 0.733 & 0.304 & 0.112 & 0.262 & -0.149 & -0.289 & -0.139 & ProdSec \\
& & & 0.297 & 0.067 & 0.349 & -0.072 & -0.196 & -0.189 & MultiSec \\
& & & & -0.022 & 0.351 & -0.418 & -0.216 & -0.359 & Prog. Assis \\
& & & & & 0.006 & 0.063 & 0.021 & -0.007 & ActionDebt \\
& & & & & & -0.399 & -0.278 & -0.553 & HumaAssis \\
& & & & & & & 0.366 & 0.740 & GDPpc \\
\end{tabular}

SocInfra: Aid to Social Infrastructure \& Services. EcoInfra: Aid to Economic Infrastructure and Services. ProdSect: Aid to Production Services. MultiSect: Aid to Multi Sector Development. Prog. Assis: Programme Assistance. ActionDebt: Aid for debt relief. HumanAssis: Aid for Humanitarian Assistance. GDPpc: GDP per capita. Trade: Trade Openness. IHDI: Inequality adjusted Human Development Index.

\subsection{Methodology}

\subsubsection{Generalised Method of Moments}

There are five main justifications for the choice of the GMM estimation approach. While the first-two are basic requirements for the employment of the GMM approach, the last-three are related advantages. First, the modelling strategy enables us to control for 
persistence in inclusive human development. Accordingly, the correlation between the IHDI and its corresponding first lag is 0.9876 which surpasses the 0.800 threshold needed to ascertain persistence in a dependent variable. Second, the $\mathrm{N}(53)>\mathrm{T}(8)$ criterion needed to employ the GMM technique is fulfilled because the number of time series in each cross section is lower than the number of cross sections. Third, the modelling approach enables the study to account for potential endogeneity by controlling for (i) the unobserved heterogeneity with time invariant omitted variables and (ii) simultaneity in all regressors by employing instrumented explanatory variables. Fourth, cross-country variations are controlled in the regressions. Fifth, consistent with Bond et al. (2001), the system GMM estimator (Arellano \& Bond, 1995; Blundell \& Bond, 1998) corrects for biases associated with the difference estimator (Arellano \& Bond, 1991).

In this study, we adopt an extension of Arellano and Bover (1995) by Roodman (2009a, 2009b) which uses forward orthogonal deviations instead of first differences because it has been shown to limit instrument proliferation and restrict over-identification (see Love \& Zicchino, 2006; Baltagi, 2008; Asongu \& De Moor, 2017). The two-step process in its place of a one-step approach is adopted in order to control for heteroscedasticity because the one-step process is consistent with homoscedasticity.

The following equations in levels (1) and first difference (2) summarize the standard system GMM estimation procedure.

$$
\begin{aligned}
& I H D_{i, t}=\sigma_{0}+\sigma_{1} I H D_{i, t-\tau}+\sigma_{2} \text { Aid }_{i, t}+\sigma_{3} \text { AidAid }_{i, t}+\sum_{h=1}^{k} \delta_{h} W_{h, i, t-\tau}+\eta_{i}+\xi_{t}+\varepsilon_{i, t} \\
& I H D_{i, t}-I H D_{i, t-\tau}= \sigma_{1}\left(I H D_{i, t-\tau}-I H D_{i, t-2 \tau}\right)+\sigma_{2}\left(\text { Aid }_{i, t}-\text { Aid }_{i, t-\tau}\right)+\sigma_{3}\left(\text { IHDAid }_{i, t}-\text { IHDAid }_{i, t-\tau}\right) \\
&+\sum_{h=1}^{k} \delta_{h}\left(W_{h, i, t-\tau}-W_{h, i, t-2 \tau}\right)+\left(\xi_{t}-\xi_{t-\tau}\right)+\varepsilon_{i, t-\tau}
\end{aligned}
$$

where, $I H D_{i, t}$ is inclusive human development in country $i$ at period $t ; I H D_{i, t-1}$ is inclusive human development in country $i$ at period $t-1 ; A_{i, t}$ is foreign aid (which includes 'aid for social infrastructure', 'aid for economic infrastructure', 'aid to the productive sector', 'aid to the multi-sector', programme assistance, action on debt and humanitarian assistance) of country $i$ at period $t ; \sigma_{0}$ is a constant; $\tau$ represents the coefficient of auto-regression; $W$ is the vector of control variables,$\eta_{i}$ is the country-specific effect, $\xi_{t}$ is the time-specific constant and $\varepsilon_{i, t}$ the error term. 


\subsubsection{Identification, simultaneity and exclusion restrictions}

In the GMM specification, it is relevant to engage concerns surrounding identification, simultaneity and exclusion restrictions. Consistent with recent literature (see Asongu\& Nwachukwu, 2016c; Dewan \& Ramaprasad, 2014), all explanatory variables are considered as predetermined or suspected variables while time-invariant omitted variables are assumed to exhibit strict exogeneity. In essence, it is unfeasible for years or time-invariant omitted variables to become endogenous in difference (see Roodman, 2009b). Therefore, the procedure for treating time invariant omitted variables is (or ivstyle) is 'iv(years, eq(diff))' whereas the gmmstyle is used for the predetermined or suspected endogenous variables.

The issue about simultaneity is tackled with lagged regressors that are used as instruments for forward differenced indicators. Accordingly, Helmet transformation is used to purge fixed effects that are likely to be associated with error terms and which could potentially bias the examined connections (Arellano \& Bover, 1995; Love \& Zicchino, 2006). The discussed transformations consist of employing forward mean-variations of variables which is different from the process of deducting previous observations from contemporary ones (see Roodman, 2009b, p. 104). This conversion ensures parallel or orthogonal conditions between forward-differenced variables and lagged values. Regardless of the number of lags, data loss is avoided by computing the discussed transformations for all observations with the exception of the last for each cross section: "And because lagged observations do not enter the formula, they are valid as instruments" (Roodman, 2009b, p. 104).

Given the above clarification, the dependent variable is affected by the time invariant omitted indicators exclusively through the predetermined or suspected endogenous variables. Furthermore, the statistical validity of the exclusion restriction is assessed with the Difference in Hansen Test (DHT) for the validity of instruments. Accordingly, in order for time invariant omitted variables to elicit inclusive human development exclusively via the endogenous explaining indicators, the alternative hypothesis of the test should be rejected. It is important to note that when employing an instrumental variable (IV) estimation procedure, rejecting the alternative hypothesis of the Sargan Over-identifying Restrictions (OIR) test means that the instruments explain the outcome variable exclusively via the predetermined or suspected endogenous variables (see Beck et al., 2013; Asongu \& Nwachukwu, 2016d), with the GMM procedure that is based on forward orthogonal deviations, the information criterion that is employed to investigate whether time invariant omitted indicators are strictly exogenous is the 
DHT. Hence, on the basis of above clarification, the exclusion restriction hypothesis is confirmed if the alternative hypothesis of the DHT connected with IV(year, eq[diff]) is rejected.

\subsubsection{Instrumental Tobit regressions}

The standard Tobit model is also adopted in order to investigate the nexus between increasing foreign aid and inclusive human development. Given that the IHDI theoretically falls between 0 and 1, estimation by Ordinary Least Squares (OLS) is inappropriate. A double-censored Tobit model is therefore employed to control for the limited range in the outcome indicator (Kumbhakar \& Lovell, 2000; Coccorese \& Pellecchia, 2010; Koetter et al., 2008; Ariss, 2010; Asongu \& Le Roux, 2017). The parameters in Tobit models are estimated by means of maximum likelihood.In accordance with Coccorese and Pellecchia (2010) and McDonald (2009), when no observations with either the value of 1 or 0 are apparent, estimating by a double-censored Tobit model is similar to estimation by a linear model because the two likelihood functions coincide. The limitation in range is consistent with our outcome variable because its minimum and maximum values are respectively of 0.129 and 0.809 .

The standard Tobit model (Tobin, 1958; Carsun \& Sun, 2007) is as follows:

$y_{i, t}^{*}=\alpha_{0}+\beta X_{i, t}+\varepsilon_{i, t}(3)$

where $y_{i, t}^{*}$ is a latent response variable, $X_{i, t}$ is an observed $1 \times k$ vector of explanatory variables and $\varepsilon_{i, t} \approx$ i.i.d. $\mathrm{N}\left(0, \sigma^{2}\right)$ and is independent variable of $X_{i, t}$. Instead of observing $y_{i, t}^{*}$, we observe $y_{i, t}$ :

$$
y_{i, t}=\left\{\begin{array}{c}
y_{i, t}^{*} \text { if } y_{i, t}^{*}>\gamma \\
0, \text { if } y_{i, t}^{*} \leq \gamma,
\end{array}\right.
$$

where $\gamma$ is a non stochastic constant. In other words, the value of $y_{i, t}^{*}$ is missing when it is less than or equal to $\gamma$.

The concern about endogeneity is addressed by using an instrumental variable Tobit model.

The instrumentation procedure for foreign aid variables is in Eq. (5) below.

$$
\operatorname{Aid}_{i, t}=\alpha+\delta_{j}\left(\operatorname{Aid}_{i, t-1}\right)+\varepsilon_{i, t}
$$


Where: $\operatorname{Aid}_{i, t}$ is a foreign aid indicator of country $i$ at period $t, \quad \alpha$ is a constant, Aid $_{i, t-1}$, represents foreign aid in country $i$ at period $t-1$, and $\varepsilon_{i, t}$ the error term. The instrumentation procedure consists of regressing the foreign aid independent variables of interest on their first lags and then saving the fitted values that are subsequently used as the main independent variables in Eq. (2). The specifications are Heteroscedasticity and Autocorrelation Consistent (HAC) in standard errors.

Since, the estimation strategy is concerned with interactive regressions; it is relevant to briefly engage potential drawbacks that could be associated interactive specifications. In accordance with Brambor et al (2006), all constitutive explanatory indicators should enter into the specifications. Moreover, for the estimated coefficients to have economic meaning, they should be interpreted as marginal impacts.

\section{Empirical results}

Tables 3-4 present GMM findings whereas Table 5-6 report Tobit estimation results. Whereas Table 3 and Table 5 disclose findings associated with four foreign aid indicators Table 4 and Table 6 report results related to three aid indicators. Each development assistance indicator is connected to two specifications which are contingent on changing conditioning information sets in order to tackle the discussed concern of instrument proliferation. Accordingly, while in the first sets of specifications, the number of instruments is less than the number of cross sections, in the second groups of specifications, the number of instruments is equal to the number of countries. It is important to note that a rule of thumb required to avoid post-estimation proliferation of instruments is that the number of instruments should not exceed the number of cross sections ${ }^{4}$. It follows that augmenting the number of control variables also concurrently increases the corresponding number of instruments. Hence, not all alternative development assistance indicators are incorporated as control variables due to issues of multicollinearity that are highlighted in bold in the correlation matrix (see Table 2).

Four principal information criteria are employed to investigate the validity of the GMM model with forward orthogonal deviations ${ }^{5}$.The findings are discussed in terms of

\footnotetext{
${ }^{4}$ We note that this rule of thumb is not violated when the instruments are equal to the number of cross sections.

5"First, the null hypothesis of the second-order Arellano and Bond autocorrelation test $(A R(2))$ in difference for the absence of autocorrelation in the residuals should not be rejected. Second the Sargan and Hansen overidentification restrictions (OIR) tests should not be significant because their null hypotheses are the positions that instruments are valid or not correlated with the error terms. In essence, while the Sargan OIR test is not robust but not weakened by instruments, the Hansen OIR is robust but weakened by instruments. In order to restrict identification or limit the proliferation of instruments,
} 
marginal and net effects of foreign aid. For example in the third column of Table 3, the conditional impact of 'aid to social infrastructure' is 0.013 while the net effect from the role of 'aid to social infrastructure' in the persistence of inclusive development is $-0.029(-0.056+$ [0.013 $\times 2.012]$ ), where 2.012 is the mean value of 'aid to social infrastructure'.

While the positive marginal impact implies growing returns from 'aid to social infrastructure', a negative net effect from the association between development assistance and the lagged inclusive development variable means that foreign aid does not sustain the persistence (or sustainability) of inclusive human development. The following findings can be established from Tables 3-4. (1) There are synergy effects from 'aid to the productive sector' and a positive net effect from 'programme assistance' ${ }^{6}$. (2) There are negative net impacts from 'aid to social infrastructure' and human assistance, albeit with positive marginal effects.

The following findings can be established from Tables 3-4. (1) There are synergy effects from 'aid for economic infrastructure'. (2) There are negative net impacts from 'aid to social infrastructure', 'aid to the productive sector' and human assistance, albeit with positive marginal effects. Most of the control variables are significant. Whereas the signs of the foreign aid control variables are broadly consistent with Asongu and Nwachukwu (2016a), the effects of GDP per capita and trade openness on the outcome variable are significant for the most part.

we have ensured that instruments are lower than the number of cross-sections in most specifications. Third, the Difference in Hansen Test (DHT) for exogeneity of instruments is also employed to assess the validity of results from the Hansen OIR test. Fourth, a Fischer test for the joint validity of estimated coefficients is also provided" (Asongu \& De Moor, 2017, p.200). ${ }^{6}$ Synergy effects are apparent with both conditional and unconditional effects are positive. 
Table 3: Social Infrastructure, Economic Infrastructure, Productive Sector and Multi Sector

\begin{tabular}{|c|c|c|c|c|c|c|c|c|}
\hline \multirow[b]{3}{*}{ IHDI (-1) } & \multicolumn{8}{|c|}{ Dependent Variable: Inequality Adjusted Inclusive Human Development } \\
\hline & \multicolumn{2}{|c|}{$\begin{array}{c}\text { Social Infrastructure } \\
\text { (SocInfra) }\end{array}$} & \multicolumn{2}{|c|}{$\begin{array}{c}\text { Economic Infrastructure } \\
(\text { EcoInfra })\end{array}$} & \multicolumn{2}{|c|}{$\begin{array}{c}\text { Productive Sector } \\
\text { (ProdSect) }\end{array}$} & \multicolumn{2}{|c|}{$\begin{array}{c}\text { Multi Sector } \\
\text { (MultiSect) }\end{array}$} \\
\hline & $\begin{array}{l}0.996 * * * \\
(0.000)\end{array}$ & $\begin{array}{l}1.024 * * * \\
(0.000)\end{array}$ & $\begin{array}{l}1.005 * * * \\
(0.000)\end{array}$ & $\begin{array}{l}1.051 * * * \\
(0.000)\end{array}$ & $\begin{array}{l}0.960 * * * \\
(0.000)\end{array}$ & $\begin{array}{l}1.038 * * * \\
(0.000)\end{array}$ & $\begin{array}{l}1.016 * * * \\
(0.000)\end{array}$ & $\begin{array}{l}1.059 * * * \\
(0.000)\end{array}$ \\
\hline Constant & $\begin{array}{l}0.025 \\
(0.126)\end{array}$ & $\begin{array}{l}\mathbf{0 . 0 5 0} * \\
(\mathbf{0 . 0 5 0})\end{array}$ & $\begin{array}{l}0.002 \\
(0.693)\end{array}$ & $\begin{array}{l}-0.020 \\
(0.183)\end{array}$ & $\begin{array}{l}0.021 * * * \\
(0.001)\end{array}$ & $\begin{array}{l}-0.016 \\
(0.210)\end{array}$ & $\begin{array}{l}-0.002 \\
(0.754)\end{array}$ & $\begin{array}{l}-0.019 \\
(0.145)\end{array}$ \\
\hline SocInfra(Ln) & $\begin{array}{l}-0.018 \\
(0.187)\end{array}$ & $\begin{array}{l}-0.056 * * * \\
(0.001)\end{array}$ & -- & --- & -- & -- & -- & -- \\
\hline EconInfra(Ln) & --- & --- & $\begin{array}{l}0.0006 \\
(0.300)\end{array}$ & $\begin{array}{l}0.0005 \\
(0.360)\end{array}$ & --- & --- & --- & --- \\
\hline ProdSect(Ln) & --- & --- & --- & -- & $\begin{array}{l}0.001 * * \\
(0.038)\end{array}$ & $\begin{array}{l}-0.001 \\
(0.154)\end{array}$ & --- & --- \\
\hline MultiSect(Ln) & --- & --- & --- & --- & -- & -- & $\begin{array}{l}0.002 \\
(0.571)\end{array}$ & $\begin{array}{l}-0.001 \\
(0.567)\end{array}$ \\
\hline SocInfra(Ln) ×SocInfra(Ln) & $\begin{array}{l}0.005 \\
(0.131)\end{array}$ & $\begin{array}{l}\mathbf{0 . 0 1 3} * * * \\
(\mathbf{0 . 0 0 0 )}\end{array}$ & --- & --- & --- & --- & --- & --- \\
\hline EconInfra $($ Ln $) \times$ EconInfra $($ Ln $)$ & --- & --- & $\begin{array}{l}-0.0001 \\
(0.566)\end{array}$ & $\begin{array}{l}-0.00007 \\
(0.763)\end{array}$ & --- & --- & --- & --- \\
\hline ProdSect $($ Ln $) \times \operatorname{ProdSect}(\mathrm{Ln})$ & --- & --- & --- & -- & $\begin{array}{l}\text { 0.0008* } \\
(0.061)\end{array}$ & $\begin{array}{l}0.001 * * * \\
(0.000)\end{array}$ & --- & --- \\
\hline MultiSect(Ln) ×MultiSect(Ln) & --- & --- & --- & --- & --- & -- & $\begin{array}{l}-0.001 \\
(0.431)\end{array}$ & $\begin{array}{l}0.0009 \\
(0.418)\end{array}$ \\
\hline Programme Assistance(Ln) & $\begin{array}{l}0.001 * * * \\
(0.006)\end{array}$ & $\begin{array}{l}\mathbf{0 . 0 0 1} * * * \\
(\mathbf{0 . 0 0 2})\end{array}$ & $\begin{array}{l}\mathbf{0 . 0 0 1} * * * \\
(\mathbf{0 . 0 0 4 )}\end{array}$ & $\begin{array}{l}\text { 0.001*** } \\
(\mathbf{0 . 0 2 1})\end{array}$ & $\begin{array}{l}0.001 * \\
(0.076)\end{array}$ & $\begin{array}{l}\mathbf{0 . 0 0 2} * * * \\
(\mathbf{0 . 0 0 0 )}\end{array}$ & $\begin{array}{l}\mathbf{0 . 0 0 0 8} * * \\
(\mathbf{0 . 0 4 3 )}\end{array}$ & $\begin{array}{l}0.0004 \\
(0.249)\end{array}$ \\
\hline Action on Debt(Ln) & $\begin{array}{l}\mathbf{0 . 0 0 1} * * * \\
(\mathbf{0 . 0 0 3 )}\end{array}$ & $\begin{array}{l}\mathbf{0 . 0 0 1} * * * \\
(\mathbf{0 . 0 0 0 )}\end{array}$ & $\begin{array}{l}0.0004 \\
(0.233)\end{array}$ & $\begin{array}{l}\text { 0.001* } \\
(0.051)\end{array}$ & $\begin{array}{l}\text { 0.001*** } \\
(0.010)\end{array}$ & $\begin{array}{l}\mathbf{0 . 0 0 1} * * * \\
(0.000)\end{array}$ & $\begin{array}{l}0.0003 \\
(0.312)\end{array}$ & $\begin{array}{l}\text { 0.0008* } \\
(0.040)\end{array}$ \\
\hline Humanitarian Assistance(Ln) & $\begin{array}{l}-0.001 \\
(0.307)\end{array}$ & $\begin{array}{l}0.001 \\
(0.282)\end{array}$ & $\begin{array}{l}-0.001 \\
(0.219)\end{array}$ & $\begin{array}{l}0.004 * * * \\
(0.000)\end{array}$ & $\begin{array}{l}-0.002 * \\
(0.065)\end{array}$ & $\begin{array}{l}0.004 * * * \\
(0.000)\end{array}$ & $\begin{array}{l}-0.0007 \\
(0.379)\end{array}$ & $\begin{array}{l}0.003 * * * \\
(0.000)\end{array}$ \\
\hline GDP per capita (Ln) & --- & $\begin{array}{l}-0.002 \\
(0.446)\end{array}$ & --- & $\begin{array}{l}-0.007 * * \\
(0.035)\end{array}$ & --- & $\begin{array}{l}-0.005 \\
(0.278)\end{array}$ & --- & $\begin{array}{l}-0.011 * * \\
(0.012)\end{array}$ \\
\hline Trade(Ln) & -- & $\begin{array}{l}0.0004 \\
(0.798)\end{array}$ & --- & $\begin{array}{l}0.004 * * \\
(0.026)\end{array}$ & --- & $\begin{array}{l}0.002 \\
(0.267)\end{array}$ & --- & $\begin{array}{l}0.006 * * * \\
(0.000)\end{array}$ \\
\hline Net Effects & na & -0.029 & na & na & 0.0018 & 0.0001 & na & na \\
\hline $\operatorname{AR}(1)$ & $(0.106)$ & $(\mathbf{0 . 1 0 5})$ & (0.118) & $(0.134)$ & $(0.094)$ & $(0.098)$ & $(0.122)$ & $(0.137)$ \\
\hline $\operatorname{AR}(2)$ & $(0.272)$ & $(0.139)$ & $(0.783)$ & $(0.270)$ & $(0.904)$ & $(0.348)$ & $(0.945)$ & $(0.265)$ \\
\hline Sargan OIR & $(0.134)$ & $(0.001)$ & $(0.083)$ & $(0.000)$ & $(0.055)$ & $(0.000)$ & $(0.127)$ & $(0.001)$ \\
\hline Hansen OIR & $(\mathbf{0 . 5 8 8 )}$ & $(0.476)$ & $(0.502)$ & $(0.658)$ & $(0.194)$ & $(0.443)$ & $(0.504)$ & $(0.597)$ \\
\hline $\begin{array}{l}\text { DHT for instruments } \\
\text { (a)Instruments in levels }\end{array}$ & & & & & & & & \\
\hline $\mathrm{H}$ excluding group & $(0.884)$ & $(0.858)$ & $(0.266)$ & $(0.402)$ & $(0.561)$ & (0.298) & $(\mathbf{0 . 7 8 8})$ & $(0.246)$ \\
\hline $\begin{array}{l}\text { Dif(null, H=exogenous) } \\
\text { (b) IV (years, eq (diff)) }\end{array}$ & $(0.334)$ & $(0.240)$ & $(0.633)$ & $(0.714)$ & (0.117) & $(0.535)$ & $(0.302)$ & $(0.775)$ \\
\hline H excluding group & $(0.655)$ & $(0.624)$ & $(0.552)$ & $(0.565)$ & $(0.044)$ & $(0.424)$ & $(0.310)$ & $(0.643)$ \\
\hline Dif(null, H=exogenous) & $(0.378)$ & $(\mathbf{0 . 2 3 3 )}$ & $(0.367)$ & $(0.632)$ & $(0.929)$ & $(0.439)$ & $(0.724)$ & $(0.382)$ \\
\hline Fisher & $3329.86 * * *$ & $884466 * * *$ & $4526.74 * * *$ & $26012.74 * * *$ & $7175.70 * * *$ & $1.20 \mathrm{e}+06 * * *$ & $7981.37 * * *$ & $231462 * * *$ \\
\hline Instruments & 29 & 37 & 29 & 37 & 29 & 37 & 29 & 37 \\
\hline Countries & 38 & 37 & 38 & 37 & 38 & 37 & 38 & 37 \\
\hline Observations & 187 & 176 & 187 & 176 & 187 & 176 & 187 & 176 \\
\hline
\end{tabular}

*******: significance levels at 1\%, 5\% and 10\% respectively. Econ: Economic. Prog: Programme. Hum: Humanitarian. DHT: Difference in Hansen Test for Exogeneity of Instruments Subsets. Dif: Difference. OIR: Over-identifying Restrictions Test. The significance of bold values is twofold. 1) The significance of estimated coefficients and the Wald statistics. 2) The failure to reject the null hypotheses of: a) no autocorrelation in the $\mathrm{AR}(1) \& \mathrm{AR}(2)$ tests and; b) the validity of the instruments in the Sargan and Hansen OIR tests. 
Table 4: Programme Assistance, Action on Debt and Humanitarian Assistance

Dependent Variable: Inequality Adjusted Inclusive Human Development

\begin{tabular}{|c|c|c|c|c|c|c|}
\hline \multirow[b]{2}{*}{ IHDI $(-1)$} & \multicolumn{2}{|c|}{ (ProgAssis) } & \multicolumn{2}{|c|}{ (ActionDebt) } & \multicolumn{2}{|c|}{ (HumanAssis) } \\
\hline & $\begin{array}{l}1.003 * * * \\
(0.000)\end{array}$ & $\begin{array}{l}1.060 * * * \\
(0.000)\end{array}$ & $\begin{array}{l}0.976 * * * \\
(0.000)\end{array}$ & $\begin{array}{l}1.036 * * * \\
(0.000)\end{array}$ & $\begin{array}{l}0.986 * * * \\
(0.000)\end{array}$ & $\begin{array}{l}1.026 * * * \\
(0.000)\end{array}$ \\
\hline Constant & $\begin{array}{l}-0.002 \\
(0.746)\end{array}$ & $\begin{array}{l}-0.035 \\
(0.132)\end{array}$ & $\begin{array}{l}0.005 \\
(0.351)\end{array}$ & $\begin{array}{l}-0.021 \\
(0.148)\end{array}$ & $\begin{array}{l}0.010 \\
(0.201)\end{array}$ & $\begin{array}{l}-0.011 \\
(0.479)\end{array}$ \\
\hline ProgAssis(Ln) & $\begin{array}{l}\text { 0.001* } \\
(0.070)\end{array}$ & $\begin{array}{l}0.003 * * * \\
(0.003)\end{array}$ & $\begin{array}{l}0.0006 \\
(0.204)\end{array}$ & $\begin{array}{l}0.0005 \\
(0.362)\end{array}$ & $\begin{array}{l}\text { 0.0008* } \\
(0.089)\end{array}$ & $\begin{array}{l}-0.0003 \\
(0.278)\end{array}$ \\
\hline ActionDebt(Ln) & $\begin{array}{l}0.0006 * * \\
(0.042)\end{array}$ & $\begin{array}{l}\mathbf{0 . 0 0 2} * * * \\
(\mathbf{0 . 0 0 0 )}\end{array}$ & $\begin{array}{l}0.001 * * \\
(0.026)\end{array}$ & $\begin{array}{l}\mathbf{0 . 0 0 1} * * * \\
(\mathbf{0 . 0 0 0 )}\end{array}$ & $\begin{array}{l}\text { 0.001* } \\
(0.051)\end{array}$ & $\begin{array}{l}\mathbf{0 . 0 0 2} * * * \\
(\mathbf{0 . 0 0 0 )}\end{array}$ \\
\hline HumanAssis(Ln) & $\begin{array}{l}-0.0007 \\
(0.494)\end{array}$ & $\begin{array}{l}\mathbf{0 . 0 0 4} * * * \\
(\mathbf{0 . 0 0 0 )}\end{array}$ & $\begin{array}{l}-0.001 \\
(0.163)\end{array}$ & $\begin{array}{l}\mathbf{0 . 0 0 3} * * * \\
(\mathbf{0 . 0 0 0 )}\end{array}$ & $\begin{array}{l}-0.0006 \\
(0.691)\end{array}$ & $\begin{array}{l}-0.002 * * \\
(0.029)\end{array}$ \\
\hline $\operatorname{Prog} \operatorname{Assis}($ Ln $) \times \operatorname{Prog} \operatorname{Assis}($ Ln $)$ & $\begin{array}{l}-0.0004 \\
(0.332)\end{array}$ & $\begin{array}{l}-\mathbf{0 . 0 0 1} * * * \\
(\mathbf{0 . 0 0 3 )}\end{array}$ & --- & --- & --- & --- \\
\hline ActionDebt(Ln) $\times$ ActionDebt $(\operatorname{Ln})$ & --- & --- & $\begin{array}{l}-0.0001 \\
(0.546)\end{array}$ & $\begin{array}{l}0.0001 \\
(0.248)\end{array}$ & --- & --- \\
\hline HumanAssis $($ Ln $) \times$ HumanAssis $($ Ln $)$ & --- & --- & --- & --- & $\begin{array}{l}-0.001 \\
(0.211)\end{array}$ & $\begin{array}{l}\mathbf{0 . 0 0 2} * * * \\
(\mathbf{0 . 0 0 0 )}\end{array}$ \\
\hline SocInfra(Ln) & $\begin{array}{l}0.002 \\
(0.144)\end{array}$ & $\begin{array}{l}\mathbf{0 . 0 0 6 * * * *} \\
(\mathbf{0 . 0 0 4 )}\end{array}$ & $\begin{array}{l}\mathbf{0 . 0 0 4} * * * \\
(\mathbf{0 . 0 0 2})\end{array}$ & $\begin{array}{l}0.005 * * \\
(0.012)\end{array}$ & $\begin{array}{l}0.003 \\
(0.112)\end{array}$ & $\begin{array}{l}\mathbf{0 . 0 0 5 * * *} \\
(\mathbf{0 . 0 0 6 )}\end{array}$ \\
\hline GDP per capita $(\mathrm{Ln})$ & --- & $\begin{array}{l}-0.008 \\
(0.196)\end{array}$ & --- & $\begin{array}{l}-0.006 \\
(0.177)\end{array}$ & --- & $\begin{array}{l}-\mathbf{0 . 0 1 0} * * \\
(\mathbf{0 . 0 1 5})\end{array}$ \\
\hline Trade(Ln) & --- & $\begin{array}{l}0.003 \\
(0.192)\end{array}$ & --- & $\begin{array}{l}0.002 \\
(0.107)\end{array}$ & --- & $\begin{array}{l}\mathbf{0 . 0 0 4} * * \\
(\mathbf{0 . 0 3 9})\end{array}$ \\
\hline Net Effects & na & 0.0008 & na & na & na & -0.0002 \\
\hline $\begin{array}{l}\text { AR(1) } \\
\text { AR(2) } \\
\text { Sargan OIR } \\
\text { Hansen OIR }\end{array}$ & $\begin{array}{l}(0.120) \\
(0.158) \\
(0.171) \\
(0.555)\end{array}$ & $\begin{array}{l}(\mathbf{0 . 1 4 3 )} \\
\mathbf{( 0 . 1 3 5 )} \\
(0.004) \\
(\mathbf{0 . 8 9 0})\end{array}$ & $\begin{array}{l}(0.117) \\
(0.820) \\
(0.292) \\
(0.494)\end{array}$ & $\begin{array}{l}(\mathbf{0 . 1 3 4 )} \\
(\mathbf{0 . 2 8 3 )} \\
(0.001) \\
(\mathbf{0 . 6 4 4 )}\end{array}$ & $\begin{array}{l}(0.103) \\
(0.287) \\
(0.215) \\
(0.599)\end{array}$ & $\begin{array}{l}(\mathbf{0 . 1 3 5}) \\
(\mathbf{0 . 2 4 6}) \\
(0.001) \\
(\mathbf{0 . 8 9 9})\end{array}$ \\
\hline $\begin{array}{l}\text { DHT for instruments } \\
\text { (a)Instruments in levels }\end{array}$ & & & & & & \\
\hline H excluding group & $(0.582)$ & $(0.877)$ & $(0.764)$ & $(0.856)$ & $(0.752)$ & $(0.804)$ \\
\hline $\begin{array}{l}\text { Dif(null, H=exogenous) } \\
\text { (b) IV (years, eq (diff)) }\end{array}$ & $(\mathbf{0 . 4 5 9 )}$ & $(0.736)$ & $(0.304)$ & $(0.401)$ & $(0.416)$ & $(\mathbf{0 . 8 0 2 )}$ \\
\hline $\mathrm{H}$ excluding group & $(0.572)$ & $(0.741)$ & $(0.449)$ & $(0.621)$ & $(0.473)$ & $(0.719)$ \\
\hline Dif(null, $\mathrm{H}=$ exogenous) & $(0.423)$ & $(0.893)$ & $(0.480)$ & $(0.503)$ & $(0.627)$ & $(0.945)$ \\
\hline Fisher & $4260.69 * * *$ & $97120.29 * * *$ & $2385.83 * * *$ & $677783 * * *$ & $1145.68 * * *$ & $1.81 \mathrm{e}+06 * * *$ \\
\hline Instruments & 29 & 37 & 29 & 37 & 29 & 37 \\
\hline Countries & 38 & 37 & 38 & 37 & 38 & 37 \\
\hline Observations & 187 & 176 & 187 & 176 & 187 & 176 \\
\hline
\end{tabular}

$* * *, * *, *$ : significance levels at 1\%,5\% and 10\% respectively. Econ: Economic. Prog: Programme. Hum: Humanitarian. DHT: Difference in Hansen Test for Exogeneity of Instruments Subsets. Dif: Difference. OIR: Over-identifying Restrictions Test. The significance of bold values is twofold. 1) The significance of estimated coefficients and the Wald statistics. 2) The failure to reject the null hypotheses of: a) no autocorrelation in the $\mathrm{AR}(1) \& \mathrm{AR}(2)$ tests and; b) the validity of the instruments in the Sargan and Hansen OIR tests. 
Table 5: Social Infrastructure, Economic Infrastructure, Productive Sector and Multi Sector

\begin{tabular}{|c|c|c|c|c|c|c|c|c|}
\hline \multirow{3}{*}{ Constant } & \multicolumn{8}{|c|}{ Dependent Variable: Inequality Adjusted Inclusive Human Development } \\
\hline & \multicolumn{2}{|c|}{$\begin{array}{c}\text { Social Infrastructure } \\
\text { (SocInfra) }\end{array}$} & \multicolumn{2}{|c|}{$\begin{array}{c}\text { Economic Infrastructure } \\
\text { (EcoInfra) }\end{array}$} & \multicolumn{2}{|c|}{$\begin{array}{c}\text { Productive Sector } \\
\text { (ProdSect) }\end{array}$} & \multicolumn{2}{|c|}{$\begin{array}{c}\text { Multi Sector } \\
\text { (MultiSect) }\end{array}$} \\
\hline & $\begin{array}{l}\mathbf{0 . 6 1 9 * * *} \\
(\mathbf{0 . 0 0 0 )}\end{array}$ & $\begin{array}{l}0.077 \\
(0.456)\end{array}$ & $\begin{array}{l}0.529 * * * \\
(0.000)\end{array}$ & $\begin{array}{l}0.018 \\
(0.778)\end{array}$ & $\begin{array}{l}\mathbf{0 . 5 4 0} * * * \\
(\mathbf{0 . 0 0 0 )}\end{array}$ & $\begin{array}{l}-0.064 \\
(0.389)\end{array}$ & $\begin{array}{l}0.528 * * * \\
(0.000)\end{array}$ & $\begin{array}{l}-0.084 \\
(0.288)\end{array}$ \\
\hline IVSocInfra(Ln) & $\begin{array}{l}-0.113 \\
(0.263)\end{array}$ & $\begin{array}{l}-0.091 \\
(0.236)\end{array}$ & --- & --- & --- & --- & -- & --- \\
\hline IVEconInfra(Ln) & --- & --- & $\begin{array}{l}0.014 \\
(0.315)\end{array}$ & $\begin{array}{l}0.029 * * * \\
(0.009)\end{array}$ & --- & --- & --- & --- \\
\hline IVProdSect(Ln) & --- & --- & --- & -- & $\begin{array}{l}-0.047 * \\
(0.094)\end{array}$ & $\begin{array}{l}0.010 \\
(0.665)\end{array}$ & --- & --- \\
\hline IVMultiSect(Ln) & --- & --- & --- & --- & --- & --- & $\begin{array}{l}-0.030 \\
(0.661)\end{array}$ & $\begin{array}{l}0.049 \\
(0.359)\end{array}$ \\
\hline IVSocInfra(Ln) ×IVSocInfra(Ln) & $\begin{array}{l}0.047 * \\
(0.053)\end{array}$ & $\begin{array}{l}0.037 * * \\
(0.044)\end{array}$ & --- & --- & --- & --- & --- & --- \\
\hline IVEconInfra(Ln) $\times$ IVEconInfra(Ln) & --- & -- & $\begin{array}{l}0.027 * * * \\
(0.001)\end{array}$ & $\begin{array}{l}0.011 * \\
(0.066)\end{array}$ & --- & --- & --- & --- \\
\hline IVProdSect(Ln) ×IVProdSect(Ln) & --- & --- & --- & --- & $\begin{array}{l}\mathbf{0 . 0 4 3} * * * \\
(\mathbf{0 . 0 0 1 )}\end{array}$ & $\begin{array}{l}0.015 \\
(0.136)\end{array}$ & --- & --- \\
\hline IVMultiSect(Ln) ×IVMultiSect(Ln) & --- & --- & --- & --- & --- & --- & $\begin{array}{l}0.041 \\
(0.145)\end{array}$ & $\begin{array}{l}0.002 \\
(0.903)\end{array}$ \\
\hline IVProgram Assistance(Ln) & $\begin{array}{l}\mathbf{- 0 . 0 7 1} * * * \\
(\mathbf{0 . 0 0 0 )}\end{array}$ & $\begin{array}{l}-\mathbf{0 . 0 3 2} * * \\
(\mathbf{0 . 0 2 0})\end{array}$ & $\begin{array}{l}-\mathbf{0 . 0 7 0} * * * \\
(\mathbf{0 . 0 0 0 )}\end{array}$ & $\begin{array}{l}-\mathbf{0 . 0 3 3} * * * \\
(\mathbf{0 . 0 0 6})\end{array}$ & $\begin{array}{l}-\mathbf{0 . 0 5 5} * * * \\
(\mathbf{0 . 0 0 1 )}\end{array}$ & $\begin{array}{l}-\mathbf{0 . 0 2 3} * \\
(0.089)\end{array}$ & $\begin{array}{l}-0.046 * * * \\
(0.005)\end{array}$ & $\begin{array}{l}-0.012 \\
(0.342)\end{array}$ \\
\hline IVAction on Debt(Ln) & $\begin{array}{l}-0.0006 \\
(0.925)\end{array}$ & $\begin{array}{l}-0.0009 \\
(0.856)\end{array}$ & $\begin{array}{l}-0.006 \\
(0.276)\end{array}$ & $\begin{array}{l}-0.006 \\
(0.162)\end{array}$ & $\begin{array}{l}-0.0007 \\
(0.911)\end{array}$ & $\begin{array}{l}-0.002 \\
(0.589)\end{array}$ & $\begin{array}{l}0.0004 \\
(0.950)\end{array}$ & $\begin{array}{l}-0.002 \\
(0.611)\end{array}$ \\
\hline IVHumanitarian Assistance(Ln) & $\begin{array}{l}-0.062 * * * \\
(0.000)\end{array}$ & $\begin{array}{l}-0.039 * * * \\
(0.000)\end{array}$ & $\begin{array}{l}-0.046 * * * \\
(0.000)\end{array}$ & $\begin{array}{l}-0.026 * * * \\
(0.000)\end{array}$ & $\begin{array}{l}-0.042 * * * \\
(0.000)\end{array}$ & $\begin{array}{l}-0.023 * * * \\
(0.001)\end{array}$ & $\begin{array}{l}-\mathbf{0 . 0 5 2} * * * \\
(\mathbf{0 . 0 0 0 )}\end{array}$ & $\begin{array}{l}-0.031 * * * \\
(0.000)\end{array}$ \\
\hline GDP per capita $(\mathrm{Ln})$ & --- & $\begin{array}{l}0.208 * * * \\
(0.000)\end{array}$ & --- & $\begin{array}{l}\mathbf{0 . 2 0 0} * * * \\
(\mathbf{0 . 0 0 0 )}\end{array}$ & --- & $\begin{array}{l}0.217 * * * \\
(0.000)\end{array}$ & --- & $\begin{array}{l}\mathbf{0 . 2 1 9} * * * \\
(0.000)\end{array}$ \\
\hline Trade(Ln) & --- & $\begin{array}{l}-0.024 * * \\
(0.041)\end{array}$ & --- & $\begin{array}{l}-0.022 * * \\
(0.045)\end{array}$ & --- & $\begin{array}{l}-0.016 \\
(0.196)\end{array}$ & --- & $\begin{array}{l}-0.019 \\
(0.118)\end{array}$ \\
\hline Net Effects & $\begin{array}{l}-0.0184 \\
2.404\end{array}$ & $\begin{array}{l}-0.0165 \\
2.459\end{array}$ & $\begin{array}{l}0.0359 \\
0.518\end{array}$ & $\begin{array}{l}0.0369 \\
\text { Synergy }\end{array}$ & $\begin{array}{l}-0.0032 \\
1.093\end{array}$ & $\begin{array}{l}\text { na } \\
\text { na }\end{array}$ & $\begin{array}{l}\text { na } \\
\text { na }\end{array}$ & $\begin{array}{l}\text { na } \\
\text { na }\end{array}$ \\
\hline LR Chi-Square & 207.158 & 247.532 & 220.597 & 260.673 & 203.151 & 243.939 & 200.538 & 241.132 \\
\hline Log Likelihood & $68.91 * * *$ & $170.45 * * *$ & $95.78 * * *$ & $196.73 * * *$ & $60.89 * * *$ & $163.26 * * *$ & $55.67 * * *$ & $157.65 * * *$ \\
\hline Pseudo $\mathrm{R}^{2}$ & -0.199 & -0.525 & -0.277 & -0.606 & -0.176 & -0.502 & -0.161 & -0.485 \\
\hline Observations & 188 & 179 & 188 & 179 & 188 & 179 & 188 & 179 \\
\hline
\end{tabular}

$* * *, * *, *$ : significance levels at $1 \%, 5 \%$ and $10 \%$ respectively. 
Table 6: Program Assistance, Action on Debt and Humanitarian Assistance

\begin{tabular}{|c|c|c|c|c|c|c|}
\hline \multirow{3}{*}{ Constant } & \multicolumn{6}{|c|}{ Dependent Variable: Inequality Adjusted Inclusive Human Development } \\
\hline & \multicolumn{2}{|c|}{$\begin{array}{c}\text { Program Assistance } \\
\text { (ProgAssis) }\end{array}$} & \multicolumn{2}{|c|}{$\begin{array}{c}\text { Action on Debt } \\
\text { (ActionDebt) }\end{array}$} & \multicolumn{2}{|c|}{$\begin{array}{c}\text { Humanitarian Assistance } \\
\text { (HumanAssis) }\end{array}$} \\
\hline & $\begin{array}{l}0.442 * * * \\
(0.000)\end{array}$ & $\begin{array}{l}-0.051 \\
(0.504)\end{array}$ & $\begin{array}{l}0.419 * * * \\
(0.000)\end{array}$ & $\begin{array}{l}-0.072 \\
(0.307)\end{array}$ & $\begin{array}{l}0.437 * * * \\
(\mathbf{0 . 0 0 0 )}\end{array}$ & $\begin{array}{l}-0.073 \\
(0.300)\end{array}$ \\
\hline IVProgAssis(Ln) & $\begin{array}{l}-0.100 * \\
(0.076)\end{array}$ & $\begin{array}{l}-0.067 \\
(0.121)\end{array}$ & $\begin{array}{l}-0.069 * * * * \\
(0.000)\end{array}$ & $\begin{array}{l}-0.030 * * \\
(0.029)\end{array}$ & $\begin{array}{l}-0.062 * * * * \\
(0.000)\end{array}$ & $\begin{array}{l}-0.026 * \\
(0.060)\end{array}$ \\
\hline IVActionDebt(Ln) & $\begin{array}{l}-0.002 \\
(0.641)\end{array}$ & $\begin{array}{l}-0.003 \\
(0.519)\end{array}$ & $\begin{array}{l}-0.007 \\
(0.364)\end{array}$ & $\begin{array}{l}-0.006 \\
(0.290)\end{array}$ & $\begin{array}{l}-0.001 \\
(0.854)\end{array}$ & $\begin{array}{l}-0.001 \\
(0.800)\end{array}$ \\
\hline IVHumanAssis(Ln) & $\begin{array}{l}-\mathbf{0 . 0 5 8} * * * * \\
(0.000)\end{array}$ & $\begin{array}{l}-\mathbf{0 . 0 3 5} * * * * \\
(0.000)\end{array}$ & $\begin{array}{l}-\mathbf{0 . 0 5 8} * * * * \\
(0.000)\end{array}$ & $\begin{array}{l}-0.036 * * * \\
(0.000)\end{array}$ & $\begin{array}{l}-0.097 * * * \\
(0.000)\end{array}$ & $\begin{array}{l}-0.064 * * * \\
(0.000)\end{array}$ \\
\hline IVProgAssis(Ln) $\times$ IVProgAssis(Ln) & $\begin{array}{l}0.013 \\
(0.563)\end{array}$ & $\begin{array}{l}0.016 \\
(0.360)\end{array}$ & --- & --- & -- & --- \\
\hline IVActionDebt(Ln) ×IVActionDebt(Ln) & --- & --- & $\begin{array}{l}0.005 \\
(0.373)\end{array}$ & $\begin{array}{l}0.004 \\
(0.362)\end{array}$ & --- & --- \\
\hline IVHumanAssis(Ln) $\times$ IVHumanAssis(Ln) & --- & --- & --- & --- & $\begin{array}{l}\mathbf{0 . 0 1 5} * \\
(\mathbf{0 . 0 7 2})\end{array}$ & $\begin{array}{l}\mathbf{0 . 0 1 1} * \\
(0.096)\end{array}$ \\
\hline IVSocInfra(Ln) & $\begin{array}{l}0.078 * * * \\
(0.000)\end{array}$ & $\begin{array}{l}\mathbf{0 . 0 5 9} * * * \\
(\mathbf{0 . 0 0 0 )}\end{array}$ & $\begin{array}{l}\mathbf{0 . 0 8 1} * * * \\
(\mathbf{0 . 0 0 0 )}\end{array}$ & $\begin{array}{l}0.062 * * * \\
(0.000)\end{array}$ & $\begin{array}{l}\mathbf{0 . 0 7 7} * * * \\
(\mathbf{0 . 0 0 0 )}\end{array}$ & $\begin{array}{l}\mathbf{0 . 0 6 1} * * * \\
(\mathbf{0 . 0 0 0 )}\end{array}$ \\
\hline GDP per capita (Ln) & --- & $\begin{array}{l}0.211 * * * \\
(0.000)\end{array}$ & --- & $\begin{array}{l}0.210 * * * \\
(0.000)\end{array}$ & --- & $\begin{array}{l}0.207 * * * \\
(0.000)\end{array}$ \\
\hline Trade(Ln) & --- & $\begin{array}{l}-0.026 * * \\
(0.027)\end{array}$ & --- & $\begin{array}{l}-0.027 * * \\
(0.025)\end{array}$ & --- & $\begin{array}{l}-0.022 * \\
(0.060)\end{array}$ \\
\hline Net Effects & na & na & na & na & -0.0835 & -0.0541 \\
\hline LR Chi-Square & $65.48 * * *$ & $167.23 * * *$ & $65.94 * * *$ & $167.22 * * *$ & $68.40 * * *$ & $169.17 * * *$ \\
\hline Log Likelihood & 205.447 & 245.922 & 205.677 & 245.918 & 206.905 & 246.891 \\
\hline Pseudo $\mathrm{R}^{2}$ & -0.189 & -0.515 & -0.190 & -0.515 & -0.198 & -0.521 \\
\hline Observations & 188 & 179 & 188 & 179 & 188 & 179 \\
\hline
\end{tabular}

***,**,*: significance levels at $1 \%, 5 \%$ and $10 \%$ respectively.

Before we conclude, it is important to note that by defining the aid variables in terms of logarithms, there has been an implicit assumption that foreign aid has diminishing marginal returns on IHDI. Hence, it is relevant to investigate whether this assumption is verified in our findings given that they are discussed in terms of marginal and net effects. Whereas this hypothesis is only confirmed for 'programme assistance' in GMM-related regressions, the use of logarithms was essential to make the variables involved comparable.

\section{Concluding Implications and Future Research Directions}

In the light of evidence that poverty has been decreasing in all regions of the World with the exception of Africa, where about 45 percent of countries in Sub-Saharan Africa did not achieve the MDG extreme poverty target, this study has assessed whether increasing foreign aid improves inclusive human development. The investigation is on 53 African countries for the period 2005-2012. The empirical evidence is based on the use of (i) the Generalised Method of Moments (GMM) to control for persistence in inclusive human development, simultaneity and time-invariant omitted variables and (ii) the Instrumental Variable Tobit regressions to account for simultaneity and a limited range in the dependent 
variable. The adopted foreign aid variables are: 'humanitarian assistance', 'action on debt' 'aid for social infrastructure', 'aid to the productive sector', 'aid to the multi sector', 'aid for economic infrastructure' and 'programme assistance'.

The following findings have been established from GMM specifications. (1) There are synergy effects from 'aid to the productive sector' and a positive net effect from 'programme assistance'. (2) There are negative net impacts from 'aid to social infrastructure' and human assistance, albeit with positive marginal effects. The following findings have been established from instrumental variable Tobit regressions. (1) There is a synergy effect from 'aid for economic infrastructure'. (2) There are negative net impacts from 'aid for social infrastructure', 'aid to the productive sector' and human assistance, albeit with positive marginal effects.

Whereas the positive impact of development assistance is in accordance with a recent strand of optimistic literature (see Kargbo \& Sen, 2014; Brempong \& Racine, 2014; Asiedu, 2014), the negative effects of foreign aid are in line with a pessimistic strand of the literature (see Monni \& Spaventa, 2013; Marglin, 2013; Titumir \& Kamal, 2013; Wamboye et al., 2013). It follows that the development outcomes of foreign aid remain open to debate in empirical literature. Unfortunately, for three principal reasons, it is not the purpose of this study to be involved in the ongoing debate. First, development assistance can be understood as a policy whose outcome substantially depends on the manner in which it is implemented. Hence, it is myopic to simplistically qualify the phenomenon as either good or bad for developing countries. On the contrary, empirics should be engaged on how such policy can be changed, maintained or improved. Second, Sustainable Development Goals (SDGs) require the wealthy industrialised countries to help poor nations in their contributions to the 17 universal objectives. Third, while development assistance could be tailored towards achieving some strategic ambitions of Donor countries, recipient governments are at least as much responsible for the outcome of funds that are disbursed by these Donor nations.

With the history of Africa's over reliance on foreign aid for development purposes, the findings of this study have some implications for multilateral agencies of development that are channelling development assistance. For example, the African Development Bank has a strategic focus of investing in infrastructural development for non-exclusive development. Hence, synergy effects from 'aid to the productive sector' and 'aid for economic infrastructure' can be leveraged for enhanced inclusive growth and development in the continent. In the light of these clarifications, continuous support by Donor countries of 
schemes underpinning the discussed strategic focus by multilateral development agencies is a step in the right direction.

When the findings are considered within a broader framework of contemporary challenges to sustainable development, foreign aid can be useful in charting developing countries toward inclusive industrialisation/capitalism as well as in debunking/clarifying provocative titles like 'foreign aid follies' (Rogoff, 2014) and/or sceptical conclusions from substantive surveys on the development outcomes of development assistance (Doucouliagos \& Paldam, 2008, 2009).

Future research can also improve on existing literature by assessing how other foreign flows (e.g. remittances) can be employed to enhance inclusive human development. Furthermore, articulating other innovative financial instruments is worthwhile, most importantly, Islamic finance, mobile banking, crowdfunding, Payment for Environmental Services and the Diaspora Investment in Agriculture initiative. As caveat to this inquiry, while some foreign aid has conditionalities attached to them, requiring specific types of action or commitment, others do not. No distinction is made between these two types of development assistance. Such conditionalities may have strong implications for the results and could also be the object of a future empirical analysis. 


\section{References}

Arellano, M., \& Bond, S., (1991)."Some tests of specification for panel data: Monte Carlo evidence and an application to employment equations",The Review of Economic Studies, 58(2), pp. 277-297.

Arellano, M., \&Bover, O., (1995). "Another look at the instrumental variable estimation of error-components models", Journal of Econometrics, 68(1), pp. 29-52.

Ariss, R. T., (2010). "On the Implications of Market Power in Banking: Evidence from Developing Countries", Journal of Banking and Finance, 34(4),pp. 765-775.

Asiedu, E., (2014). "Does Foreign Aid in Education Promote Economic Growth? Evidence From Sub-Saharan Africa", Journal of African Development, 16(1), pp. 37-59.

Asiedu, E., \& Nandwa, B., (2007). "On the Impact of Foreign Aid in Education on Growth: How relevant is heterogeneity of aid flows and heterogeneity of aid recipients?",Review of World Economics, 143(4), pp. 631-649.

Asongu, S. A., (2013). "Globalisation and Africa: Implications for Human Development", International Journal of Development Issues, 12(3), pp. 213-238.

Asongu, S. A., (2016). "Reinventing Foreign Aid for Inclusive and Sustainable Development: Kuznets, Piketty and the Great Policy Reversal", Journal of Economic Surveys, 30(4),pp. 736-755.

Asongu, S. A., \& De Moor, L., (2017). "Financial globalisation dynamic thresholds for financial development: evidence from Africa", The European Journal of Development , 29(1), pp. 192-212.

Asongu, S. A., Efobi, U., \& Beecroft, I., (2015). "Inclusive Human Development in Pre-crisis Times of Globalization-driven Debts", African Development Review, 27(4), pp. 428-442.

Asongu, S. A. \& Jellal, M., (2016). "Foreign aid fiscal policy: theory and evidence", Comparative Economic Studies, 58(2), pp.279-314.

Asongu, S. A., \& Le Roux, S., (2017). "Enhancing ICT for inclusive human development in Sub-Saharan Africa", Technological Forecasting and Social Change, 118(May), pp. 44-54.

Asongu, S.A, \& Nwachukwu, J. C., (2016a). "Foreign Aid and Inclusive Development: Updated Evidence from Africa, 2005-2012”, Social Science Quarterly, DOI: $10.1111 /$ ssqu. 12275 .

Asongu, S. A, \&Nwachukwu, J. C., (2016b). "The role of governance in mobile phones for inclusive human development in Sub-Saharan Africa", Technovation, 55-56 (SeptemberOctober), pp. 1-13. 
Asongu, S.A, \& Nwachukwu, J. C., (2016c). "The Mobile Phone in the Diffusion of Knowledge for Institutional Quality in Sub Saharan Africa", World Development, 86(October), pp. 133-147.

Asongu, S.A, \& Nwachukwu, J. C., (2016d)."Foreign aid and governance in Africa", International Review of Applied Economics, 30(1), pp. 69-88.

Baltagi, B. H., (2008). "Forecasting with panel data", Journal of Forecasting, 27(2), pp. 153173.

Banerjee, A., \& He, R., (2008). "Making Aid Work", InReinventing Foreign Aid, ed. Easterly, W., The MIT Press: Massachusetts, pp. 47-92.

Banuri, T., (2013). "Sustainable Development is the New Economic Paradigm", Development, 56(2), pp. 208-217.

Brambor, T., Clark, W. M., \&Golder, M., (2006). "Understanding Interaction Models:Improving Empirical Analyses”, Political Analysis, 14(1),pp. 63-82.

Beck, T., Demirgüç-Kunt, A., \& Levine, R., (2003), "Law and finance: why does legal origin matter?",Journal of Comparative Economics, 31(4), pp. 653-675.

Blundell, R., \& Bond, S., (1998). "Initial conditions and moment restrictions in dynamic panel data models", Journal of Econometrics, 87(1), pp. 115-143.

Bond, S., Hoeffler, A., \&Tample, J., (2001). "GMM Estimation of Empirical Growth Models", University of Oxford.

Carson, R. T., \& Sun, Y., (2007).“The Tobit model with a non-zero threshold”, Econometrics Journal, 10(3), pp. 488-502.

Chang, H-J., (2008). Bad Samaritans: The Myth of Free Trade and the Secret History of Capitalism.Bloomsbury Press; Reprint edition (December 23, 2008).

Coccorese, P., \& Pellecchia, A., (2010). “Testing the 'Quiet Life' Hypothesis in the Italian Banking Industry”, Economic Notes by Banca deiPaschi di Siena SpA, 39(3),pp.173-202.

Dewan, S., \& Ramaprasad, J., (2014). "Social media, traditional media and music sales", MIS Quarterly, 38(1), pp. 101-128.

Doucougliagos, H., \& Paldam,M., (2008). "Aid effectiveness on growth: a meta study". European Journal of Political Economy, 24(1), pp. 1-24.

Doucouliagos, H., \& Paldam, M., (2009).“The aid effectiveness literature: the sad results of 40 years of research”, Journal of Economic Surveys, 23(3), pp. 433-461.

Duflo, E., \& Kremer, M., (2008). "Use of Randomization in the Evaluation of Development Effectiveness", In Reinventing Foreign Aid, ed. Easterly, W., The MIT Press: Massachusetts, pp. 93-120. 
Easterly, W., (2002)."The cartel of good intensions: the problem of bureaucracy in foreign aid”, The Journal of Policy Reform, 5(4), pp. 223-250.

Easterly, W., (2006)."Planner versus searchers in foreign aid”, Asian Development Review, 23(1), pp. 1-35.

Easterly, W., (2008). Reinventing Foreign Aid, The MIT Press: Massachusetts.

Efobi, U., Beecroft, I., \&Asongu, S. A., (2014). "Foreign aid and corruption: clarifying murky empirical conclusions", African Governance and Development Institute Working Paper No. 14/025, Yaoundé.

Fields, G., (2001). Distribution and Development, A New Look at the Developing World. Russel Sage Foundation, New York, and The MIT Press, Cambridge, Massachusetts, and London.

Fosu, A. K., (2015a). "Growth, Inequality and Poverty in Sub-Saharan Africa: Recent Progress in a Global Context", Oxford Development Studies, 43(1), pp. 44-59.

Fosu, A. K., (2015b). Growth and Institutions in African Development, First edited by Augustin K. Fosu, , Routledge Studies in Development Economics: New York.

Fosu, A. K., (2015c). Growth and institutions in African Development, in Growth and Institutions in African Development, First edited by Augustin K. Fosu, 2015, Chapter 1, pp. 1-17, Routledge Studies in Development Economics: New York.

Ghosh, J., (2013). "Towards a Policy Framework for Reducing Inequalities", Development, 56(2), pp. 218-222.

Gyimah-Brempong, K., \& Racine, J. S., (2014). "Aid and Economic Growth: A Robust Approach”, Journal of African Development, 16(1), pp. 1-35.

Jones, S., Page, J., Shimeles, A., \& Tarp, F., (2015). "Aid, Growth and Employment in Africa", African Development Review, Supplement: Special Issue on "Aid and Employment", 27, ( S1), pp. 1-4.

Jones, S., \& Tarp, F., (2015). "Priorities for Boosting Employment in Sub-Saharan Africa: Evidence for Mozambique", African Development Review, Supplement: Special Issue on "Aid and Employment", 27, ( S1), pp. 56-70.

Kargbo, P. M., \& Sen, K., (2014).“Aid Categories that Foster Pro-Poor Growth: The Case of Sierra Leone", African Development Review, 26(2), pp. 416-429.

Krause, U., (2013). "Innovation: The new Big Push or the Post-Development alternative?" Development, 56(2), pp. 223-226. 
Koetter, M., Kolari, J. W., \& Spierduk, L. (2008). "Efficient Competition ?Testing the 'Quiet Life' of U.S Banks with Adjusted Lerner Indices", Proceedings of the $44^{\text {th }}$ 'Bank Structure and Competition' Conference, Federal Reserve Bank of Chicago.

Kuada, J. (2015). Private Enterprise-Led Economic Development,In J. Kuada (Ed.), SubSaharan Africa The Human Side of Growth, Palgrave Macmillan: New York.

Kumbhakar, S. C., \& Lovell, C. A. K. (2000). Stochastic Frontier Analysis, Cambridge MA: Cambridge University Press.

Love, I., \& Zicchino, L., (2006). "Financial Development and Dynamic Investment Behaviour: Evidence from Panel VAR". The Quarterly Review of Economics and Finance, 46(2), pp. 190-210.

Lustig, N., (2011). “The Knowledge Bank and Poverty Reduction”, Working Papers 209, ECINEQ, Society for the Study of Economic Inequality.

Marglin, S. A., (2013). “Premises for a New Economy”, Development, 56(2), pp. 149-154.

McDonald, J., (2009). "Using Least Squares and Tobit in Second Stage DEA Efficiency Analyses”, European Journal of Operational Research, 197(2), pp. 792-798.

Michel, J., (2016). "Beyond Aid: the Integration of Sustainable Development in a Coherent International Agenda", Centre for International Private Enterprises, http://www.cipe.org/publications/detail/beyond-aid-integration-sustainable-developmentcoherent-international-agenda (Accessed: 19/07/2016).

Monni, S., \& Spaventa, A., (2013). "Beyond GDP and HDI: Shifting the focus from paradigms to politics", Development, 56(2), pp. 227-231.

Mshomba, R. E., (2011). Africa and the World Trade Organization.Cambridge University Press; Reprint edition (February 21, 2011).

Obeng-Odoom, F. (2013). "Africa's Failed Economic Development Trajectory: A Critique", African Review of Economics and Finance, 4(2), pp. 151-175.

Osabuohien, E. S., \& Efobi, E. R., (2013). “Africa's Money in Africa”, South African Journal of Economics, 81(2), pp. 292-306.

Page, J., \& Shimeles, A., (2015). "Aid, Employment and Poverty Reduction in Africa", African Development Review, Supplement: Special Issue on "Aid and Employment", 27,(S1), pp. 17-30.

Page, J., \& Söderbom, M., (2015). "Is Small Beautiful? Small Enterprise, Aid and Employment in Africa", African Development Review, Supplement: Special Issue on "Aid and Employment", 27,(S1), pp. 44-55.

Pritchett, L., (2008). "It Pays to Be Ignorant: A Simple Political Economy of Rigorous Program Evaluation", In Reinventing Foreign Aid, ed. Easterly, W., The MIT Press: 
Massachusetts, pp. 121-144.

Pritchett, L., \& Woolcook, M., (2008). "Solutions When the Solution Is the Problem: Arraying the Disarray in Development", In Reinventing Foreign Aid, ed. Easterly, W., The MIT Press: Massachusetts, pp. 147-178.

Quartey P., \& Afful-Mensah, G., (2014), Foreign Aid to Africa: Flows, Patterns and Impact, in Monga $\mathrm{C}$ and Lin $\mathrm{J}$ (eds), Oxford Handbook of Africa and Economics, Volume 2: Policies and Practices, Oxford University Press, Oxford, UK.

Radelet, S., \& Levine, R., (2008). "Can We Build a Better Mousetrap? Three New Institutions Designed to Improve Aid Effectiveness", In Reinventing Foreign Aid, ed. Easterly, W., The MIT Press: Massachusetts, pp. 431-460.

Rogoff, K., (2014). "Foreign-Aid Follies", Project Syndicate, https://www.projectsyndicate.org/commentary/kenneth-rogoff-urges-caution-in-helping-poor-countries-todevelop (Accessed: 30/08/2014).

Roodman, D., (2009a). "A Note on the Theme of Too Many Instruments", Oxford Bulletin of Economics and Statistics, 71(1), pp. 135-158.

Roodman, D., (2009b). "How to do xtabond2: An introduction to difference and system GMM in Stata", Stata Journal, 9(1), pp. 86-136.

Sen, A., (1979a). "Personal Utilities and Public Judgements: Or What's Wrong with Welfare Economics?”,Economic Journal, 89(355), pp. 537-558.

Sen, A., (1979b). "Issues in the Measurement of Poverty", Scandinavian Journal of Economics, 81(2), pp. 285-307.

Sen, A., (1997). "Editorial: Human capital and human capability", World Development, 25(12), pp. 1959-1961..

Sen, A., (1999). "The Possibility of Social Choice", American Economic Review, 89(3), pp. 349-378.

Simpasa, A, Shimeles, A., \& Salami, A. O., "Employment Effects of Multilateral Development Bank Support: The Case of the African Development Bank", African Development Review, Supplement: Special Issue on "Aid and Employment”, 27,( S1), pp. 3143.

Stiglitz, J. E., (2007). Making Globalization Work. W. W. Norton \& Company; Reprint edition (September 17, 2007).

Titumir, R. A. M., \& Kamal, M. (2013). "Growing Together Sustainably: A zero-poverty post 2015 development framework”, Development, 56(2), pp. 172-184.

Tobin, J., (1958). "Estimation of relationships for limited dependent variables",Econometrica 26(1), pp. 24-36. 
Wamboye, E., Adekola, A., \&Sergi, B. S., (2013). "Economic Growth and the Role of Foreign Aid in Selected African Countries", Development, 56(2), pp. 155-171.

World Bank (2015). "World Development Indicators", World Bank Publicationshttp://www.gopa.de/fr/news/world-bank-release-world-development-indicators2015 (Accessed: 25/04/2015). 